\title{
The Challenges of Democratization and Good Governance in Guinea-Bissau
}

\author{
Iaia Ture \\ School of Public Administration and Policy, Renmin University Of China, China \\ E-mail: tureiaia@hotmail.com
}

Received: May 22, 2017 Accepted: June 6, 2016 Online published: June 22, 2017

doi:10.5296/jpag.v7i2.11261 URL: https://doi.org/10.5296/jpag.v7i2.11261

\begin{abstract}
Guinea-Bissau is a small country by size, yet is well-known for chaos. The country has always been affected by political instability marked by constant coup d'états and civil upheavals. This paper investigated the historical relationship between democratization process and good governance in Guinea-Bissau. The paper analysed the challenges experienced from when the country was a one-party state to when it became a multi-party democracy. The paper found that politicians used government institutions and abused power for their personal benefits. In order to restore sanity via democratization in Guinea Bissau, it is recommended that an effective system of governance which is capable of combating poverty and promoting community development, be installed by the people.
\end{abstract}

Keywords: democratization, good governance, political instability, corruption.

\section{Introduction}

Starting from the 1990s, Guinea-Bissau has been experimenting with the practice of democracy. It has coordinated efforts to oppose the tendency of governmental depression which, hitherto, typified political life in developing countries in Africa. For over two decades now, political lawlessness and bad governance by personalized single-party regime and barbarous dictatorship has left the country politically disbanded and an immobilized population devastated by poverty.

The late 1980s was an era marked by financial crisis that profoundly dishevelled the political systems of many developing countries in Eastern Europe. At the same time Africa was found immersed in a deep economic crisis. Some West African countries like Guinea-Bissau, Mali, Burkina Faso, Ghana, Ivory Coast, and Senegal had been trying to overcome the crises by appealing for aid from international financial organizations like the International Monetary Fund (IMF) and the World Bank (WB). Other African countries like Angola, Mozambique 
and Benin continued to insist on retaining an economic system based on centralized power assisted by an authoritarian single party system (Cardoso Carlos, 1995).

In May of 1991 the regime of African Party for Independence of Guinea and Cape Verde (in Portuguese PAIGC) led by president Nino Vieira started the first attempt to one of the most intermittent political administrative reforms. It reviewed the constitution of 1984 to, among other changes, abolish Article iv of the constitution, which enshrined the PAIGC as "the leading political force of society and the State", and at the same time approved the new law which allowed multiparty and freedom of the press. It also permitted formal institutions to be elected democratically, then, setting up the separation of powers (legislative, judiciary and executive), and fairly well organized civil society groups. Then, Guinea-Bissau was classified as a country on its way to democratization at the time.

Guinea-Bissau as one of the poorest countries in the world (World Bank, 2015), could not escape the demand for democracy. From 1991 to 1992, more than 20 political parties were legalized as a result of democratization. Three years after the introduction of the first changes to the constitution, legislative and presidential elections were held for the first time in the history of the country. The elections were considered unanimously by the international community as having been free and fair. Following these results, the government was formed taking into account the outcome of the elections results. PAIGC came out as winner of the elections based on results from the polls (Cardoso, 1995). Nevertheless, the intensity with which the ongoing democratization process could be conducted in a reasonable democracy and ensure good governance especially in this new century remains a concern. It begged the question, what is the situation of democratization process and good governance in Guinea-Bissau? This question constitutes the focal point of the paper.

\section{Experiencing Democratization}

Democracy can be a good thing if it is used correctly and with a sincere heart without the caprice of manipulating the aspirations of the people. The way democracy was imposed on Africa tended toward misguiding Africans. The way democracy is implemented in Africa is utterly against our reality and most of time even contradicts our cultural values. Pure democracy can only work if the local reality and cultural values are considered. And people can better rule themselves if they understand what democracy is.

Over the past decades, political scientists and experts in other fields have been trying to define the concept of democracy, but there is no common concept of democracy. Schumpeter (1943) defined it as a means by which "individuals acquire the power to decide by means of a competitive struggle for the people's vote." Abraham Lincoln (1809-1865) pointed out that, Democracy is the government of the people, by the people, for the people. Democratization is a process which leads to a more open, more participatory, less authoritarian society (Boutros Ghali, UN - An Agenda for Democratization, 1996). According to Huntington (1991) leaders are selected through fair, honest and periodic elections.

Following the wave of global political liberalization and the end of the Cold War, the PAIGC became aware of the coming political challenges and decided to go down the one-party 
system ending, and then change its left-wing political ideology theory to solve the crisis. The political project of institutionalization of revolutionary democracy, the concept of Leninist origin proposed by Amílcar Cabral - founding leader of Guinean nationality and Cape Verde was replaced by the International Monetary Fund (IMF) and World Bank (WB) policies. The government of PAIGC renegotiated foreign debt and secured new credits (Koudawo, 2001; Mendy 1996).

In 1990, President João Bernardo Vieira announced to the Central Committee of PAIGC that the party would adopt a multi-party framework; taking into account that the one-party regime was doomed to failure (Nóbrega, 2003). In February 1991, PAIGC held the second extraordinary congress, which expressed the commitment of the party to make the necessary changes for the introduction of a multiparty system in Guinea-Bissau. For the first time Congress held elections to the Central Committee by secret ballot until then the method was voting arm in the air. This shift meant to demonstrate to the civil society and the international community the intention of the party to carry out democracy.

In 1991 the ruling PAIGC gave first transitional step towards a multiparty system, with the abolition of Article iv of the Constitution of 1984 by the National People's Assembly. The PAIGC decided to create at that time a multi-party committee in charge of designing a new constitution that orients the country within a multiparty system. There was the argument that the commission created in August 1992 helped the PAIGC to delay the transfer of power to National People's Assembly that included a multi-emergent opposition (Koudawo, 2001). The process however gave no speed signals such as in Cape Verde. Having emerged so within the PAIGC internally, a call for faster process of democratization and renewal of the party, the internal rivalry became critical in the party and the PAIGC divided into three factions: Reformists, Conservatives and Liberals.

Although the liberals were in favour of political openness and pluralism, they preferred to establish internal propensities within the PAIGC, a one-party system. However, with a more internal democratic practice, the liberals argued that there was no a qualified opposition party with the reputation and the ideal to improve what existed (Cardoso, 1995). The scheme provided that this kind of internal democracy allowed the country to develop, maintain stability of the current system. But for reformers that was not enough, and they proposed to go further, that is, party would have the courage to open up the political dispute with other political formations and accept the alternation in power. They considered that only a Western type of democracy, while retaining certain achievements of the time of the struggle for independence, was liable to advance the country. Most of the young technocrats were those who had just returned from schools (abroad) in countries where democratic values were encouraged, the group presented an important document called "Carta dos 121" to PAIGC to speed democratic reform process. The conservative wing, on the other hand, fought to preserve the inherited privileges from during the fight for independence. They totally opposed the idea (Cardoso, 1995).

Democratization in Guinea-Bissau began involuntarily and undesirable way. PAIGC never wanted to move to democracy. The party was not yet ready for the political liberalization. 


\section{1) Macrothink}

Journal of Public Administration and Governance

ISSN 2161-7104

2017, Vol. 7, No. 2

Due to the economic and social crises that plagued the country forced situation to democratization process. President Nino Vieira made uneasy decision to a new political administrative reform. Cardoso stated due the internal and external pressure including from international community, PAIGC later signed a letter indicating the party's commitment to adopt the proposal of multi-party committee by the one-party National People's Assembly. On 21 February 1993, the National People's Assembly of mono party system ruled by the PAIGC anticipated and approved the new constitution and creates the basic conditions to democratization.

On 3 July 1994, the country held her first general elections. The PAIGC "liberators" won 62 (46.3\% of votes) seats out of 102 seats of National People's Assembly. Movemento Ba-fata got 19 seats, Party for Social Renewal "PRS" got 12 seats, União Para Mudança got 6 seats, and Struggle Front for the National Independence of Guinea "FLING" got 1 seat, and all the opposition parties together got total of 38 seats. While in presidential elections, João Bernardo "Nino" Vieira, candidate supported by PAIGC, won with $46.3 \%$ of vote and his opponent Koumba Yala, candidate of Party for Social Renewal came second with $21.8 \%$ (CNE1994, G-BENC, 1994; AED, 1994; IU, 2009). However, because no one candidate achieved $51 \%$ of the votes according to the law, the two most voted candidates must run-off. On August 7, 1994, the country held second round of presidential elections between Nino Vieira and Koumba Yala (G-BENC, 1994). Nino Vieira defeated his rival with 52\% of votes against $48 \%$ of Kumba Yala supported by other opposition parties (See elections result as below tables 1 and 2).

Table 1. National People's Assembly Election

\begin{tabular}{|l|l|l|l|}
\hline Party & Votes & $\%^{*}$ & Seats \\
\hline \multirow{2}{*}{ PAIGC } & 134982 & 37,92 & 62 \\
\hline UMB-MB & 57566 & 16,17 & 18 \\
\hline PRS & 36797 & 10,34 & 6 \\
\hline PCD & 15411 & 8,42 & 12 \\
\hline PUSD & 8286 & 4,33 & - \\
\hline FLING & 7475 & 2,33 & - \\
\hline FCG-SD & 494 & 2,10 & 1 \\
\hline
\end{tabular}

Source: Guinea-Bissau National Electoral Commission, 1994 
Table 2. Presidential election, first round

\begin{tabular}{|l|l|l|}
\hline Candidate & Votes & $\%$ \\
\hline João B. Vieira & 142577 & 46,20 \\
\hline KoumbaYala & 67518 & 21,88 \\
\hline Domingos F. Gomes & 53825 & 17,44 \\
\hline Carlos D. Gomes & 15645 & 5,07 \\
\hline François K. Mendy & 8655 & 2,80 \\
\hline BubacarDjaló & 8506 & 2,76 \\
\hline Víctor S. Maria & 6388 & 2,07 \\
\hline Antonieta R. Gomes & 5509 & 1,79 \\
\hline
\end{tabular}

\section{Source: Guinea-Bissau National Electoral Commission, 1994}

\section{The Origin of Political Instability}

The situation of governance in Guinea-Bissau is that of depression, administrative defect, and social disharmony, economic and financial impoverishment (Ture, 2016). The country has marked a series of political instability amidst constitutional interruption and military coup d'état with amazing records. There were coups in 1980, 1985, 1992, 1998, 2000, 2004, 2009, 2010, April 2012 and October 2012. According to the Government of Guinea-Bissau "the high political involvement of the defence and security forces (FDS) is one of the main causes of the cycle of instability. The country witnessed 17 coups and attempted coups since the country's independence (Terra Ranka, 2015). The country has become famous on the continent due to its successive coups, oppressive politics, and autocratic and violent practices.

\section{Theatre of Political Errors}

No elected President or government fulfils their mandate to the end of the term in Guinea-Bissau. The post of President of the Republic of Guinea-Bissau drags with it the "curse" of a democratically elected political figure never to reach the end of his term. Four Presidents ousted by coup d'états in a democratic era. One was murdered and one President died from an illness. This is the "curse" of Guinean presidential elections after opening to multiparty system in 1991.

Since the independence of Guinea-Bissau, on September 24, 1973, the country had 14 Presidents, and four of them were democratically elected in pluralist elections. According with Expresso (January 10, 2012) and Jornal O Pais (January 11, 2012), there was never a presidency which ended the term in pluralistic elections in Guinea-Bissau. "Nino" Vieira won the 1994 presidential elections and was overthrown by the military in 1998/99, Kumba Yala in 2000 and was dismissed three years later, and again President Nino Vieira was elected in 2005 presidential elections after six years of political exile in Portugal, and killed in 2009. 


\section{Ml Macrothink}

Journal of Public Administration and Governance

ISSN 2161-7104

2017, Vol. 7, No. 2

Guinea-Bissau is a country that faces a problem of chronic political instability. Rulers have always chosen antagonism. The serious problem of Guinea-Bissau is the weakness of the state and poor governance due constant change of government. During the rule of President Koumba Yala (2000-2003), he set a bad record in exchange of governments when in less than three years he exchanged 5 different governments, an average of 8 months in office for each government. A worse record came under the presidency of Jose Mario Vaz, current President (2014-2017), he set a new record in exchange of governments during his second year in office, he exchanged 5 governments, an average of 4 months and 5 days of mandate for each government, the mortality of government mandate in Guinea-Bissau is too short-lived. Total average of 10 prime ministers indeed with 10 different governments in 5 years. This gratuitous change blockades the country's development process. According to the European Union ambassador to Bissau, Victor Madeira dos Santos, "the donors cannot commit to unstable governments, when governments change constantly and with bad ministers and good ministers, without stability there will be no development" (Guinendade, September 30, 2016).

The constant upheavals in Guinea-Bissau, non-compliance with electoral programmes, the successive military coups, fragile and vulnerable economy, corruption, bad governance, poverty, and the absence of social justice led to current political instability.

See figure -1 , the figure shows the main cause of political instability in Guinea-Bissau.

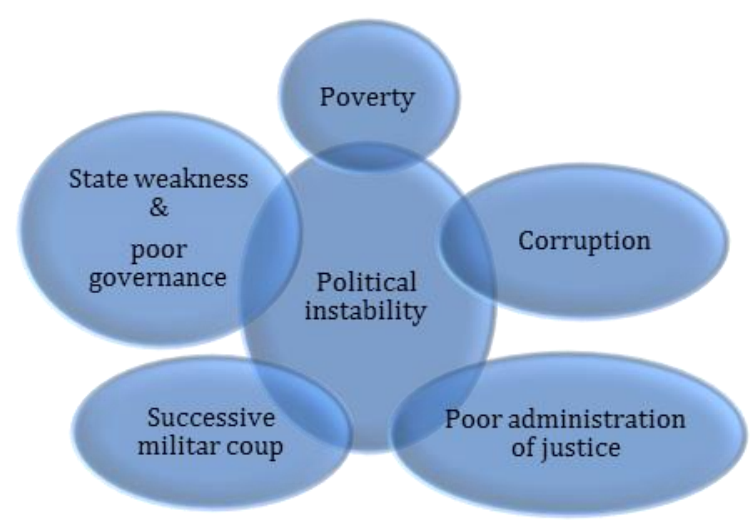

Figure 1.

Source: The Author

\section{Military Coup during the Single-party System}

The first digress signals procedure in regarding to the "revolutionary ideology" party was seen in early mandate of the first President of Guinea Bissau, Luis Cabral, one of the main leader for the anti-colonial movement. His leadership was marked by instability and a number of murdered leaders. The discovery of two mass graves containing about 500 bodies a year after the coup of November 14, 1980, served as a witness for his brutality and serious repressive policy which brought disillusionment and, in the context of an economic crisis, increased the withdrawal of foreign participation in politics and the economy, particularly in agricultural activities (MENDY, 1996). 
Most of successful and other failed coups attempts in single party system and democratic periods of Guinea-Bissau were consequences of the power struggle and internal contradictions between the top elites of the PAIGC government. According to Mendy and Koudawo (1996) during the political history of the authoritarian regime of Guinea-Bissau only one coup was successfully achieved which was led by General João Bernardo Vieira in 1980. In October 1985, the then first vice president, Paulo Correia and former Attorney General, Viriato Pã, were accused of trying to overthrow the government by violence; fifty other alleged associates were subsequently arrested, imprisoned and executed. As Cardoso (1996:29) described: "the events of October 1985 deeply shook the PAIGC image not only externally, but also, fundamentally, at the international level."

The first military coup occurred on 14 November 1980, six years after the country's independence, Luis Cabral, the first President of Guinea-Bissau was overthrown by a military group called the "Re-adjusting Movement of November 14th" led by then Prime Minister, João Bernardo (Nino) Vieira. The coup carried out successfully by the "Re-adjusting Movement" was a result of "unanimous policy" applied to the restricted class of political leaders of the party-state. Without effective mechanisms for the resolution of internal conflicts, no other legal political party to which join together to challenge the status quo, with the prevalence of an atmosphere of fear and insecurity, anxieties and frustrations, political factionalism and power struggles the highest echelons of the party-state inevitably led to this historic event (Mendy, 1996).

\section{Coup Justification}

In Guinea-Bissau all political actors and protagonists of the various conflicts refer to Amilcar Cabral (founding father of the nation) to give legitimacy to their cleat action (Djalo, 2000). The leader of "Re-adjusting Movement of November 14, 1980 coup", General João Bernardo (Nino) Vieira, justified his coup as a warfare against human rights violations, discrimination, abuse of power, social inequality, inhuman attitude, excessive executions, economic crisis and poverty. At that time there was a big privilege of government top-job amongst party leaders and corruption in the state apparatus, unimaginable difference between a ruling class living standard and ordinary people. While rulers were living luxurious lives, the masses were deprived of the most basic needed food and others necessities.

\section{Corruption in Guinea-Bissau's Public Administration System}

In recent years corruption became an infamous word in governance. Corruption has been seen as the major obstacle in the path to good governance and international organizations have been increasingly involved in combating corruption in developing countries. Guinea-Bissau, just as any other country in the world, dreamed to achieve good governance but corruption has stopped the country's development. Nye (1967:417) sees corruption as a behaviour which deviates from the formal duties of a public role because of private (personal, close family, private clique) pecuniary or status gains; or violates rules against the exercise of certain types of private-regarding influence." Corruption is fashionable in Guinea-Bissau's public administration system. The leaders are practicing corruption publicly. The abuses of power, impunity, and misuse of the state power for the individual benefit are now too perspicuous in 
the country.

The political system itself is corrupt, which clearly hinders the liberation of the country from corruption, politicians' gain their lives on the basis of corruption. Now the richest people in the country are all politicians and their close collaborators. Politician-businessman or Businessman-politician retains the national wealth of Guinea-Bissau. The underlying corruption is of worrisome proportions in the country. The Guinean Psychologist, Filomeno de Pina, said that: "we live in this absurd and addictive reality, in the middle as a guarantee of security of the parallel-trading, between business relationship and the exercise of leadership as a politician. Politicians receive gifts and money as the commission to be able to provide you service" (Gumbe.com, 2016). Politicians are accustomed of an easy and luxurious life, over 43 years of independence there are numerous commercial companies and they are still increasing which are associated with political figures and some are belonging to political leaders "politicians-businessmen." Citizens are required to pay first a bribe (Suku Di Bas) to gain access to government services.

The biggest challenge in the system remains, how to judge those "thieves" accused of stealing public money when you have corrupt judges with lack of integrity, involving in bribery acts and other dishonest practices just for following money. A corrupt judge who is living within a corrupt system does not have the moral conditions to judge a corrupt man who is feeding the system. The legal system lives on money and then it has to privilege the upper classes and protect corrupts. The system favours the great crime, because impunity encourages more corruption. President of Guinea-Bissau, Jose Mario Vaz, accused Judiciary of corruption and misuse of power in favour of personal interest. He stated that "there is a small group in the judiciary system that manipulates justice in favour of their own interests, family and friends and trying to get in hands interesting processes that generate millions" (Novas Da Guine-Bissau; O democrata; Intellectual Balantas na Diaspora, October 5, 2014).

According to a UN human rights expert, Monica Pinto, (Radio ONU; Conosaba; Ditadura do Consenso, October 16, 2015,) "justice in Guinea-Bissau does not reach people, it is expensive" and that the country lacks of a Free State sponsorship system. Impunity is very high in the country. Mónica Pinto said that, "the norms must conform to the international commitments and the reality of the country." The study on impunity in Guinea-Bissau conducted by Guinean Human Rights League (LGDH) in 2013, reveals that there is consensus on the dramatic moment in which the country is, summarizing the idea that "Guineans are at risk" and that "the state has dead". According with the study "it is consensual that Guinean society is the victim of state impunity - due to its absence." The state no longer fulfils its responsibility to defend the fundamental rights of citizens as the right to life (Guine-Bissau 40 anos de Impunidade, 2013).

Corruption brought disorder and indiscipline in public administration system. Police have no respect for the law, they are not serving and protecting the public, they are just manipulating the system in the road and airport by taking people's money without charging you with a crime or some police simply will stop you to ask for the breakfast. And even when you committed a criminal infraction they don't charge you to be prosecuted according with the 


\section{Macrothink}

Journal of Public Administration and Governance

ISSN 2161-7104

2017, Vol. 7, No. 2

law, they just ask you simple questions: "How much can you pay? How much do you have?" Any amount you have will not be going to government treasury. It is going to end up in the personal pockets. Corruption contaminated the public administration now public servants before providing you any kind service he/she asks you to pay first an extra commission "Suku Di Bas". President of Guinea-Bissau, Jose Mario Vaz, considered that there is "imperious" to end "embezzlement, corruption and misuse of procedures that have become breadwinners and way of life for many public servants who display signs of wealth incompatible with known sources of income" (Novas Da Guine-Bissau; O democrata, October 5, 2014).

Guinea-Bissau has been ruled and controlled by corrupt political elites which use government tools to private benefits and getting rich illegally in the name of the people. According with Transparency International Guinea-Bissau is ranked in 158th out of 166th countries most corrupted country in the world (Transparency International, 2016). Politicians use their immunity to practice corruption and mismanaging state affairs while they are narcissists.

See figure 2 - the figure shows the governance challenging problems.

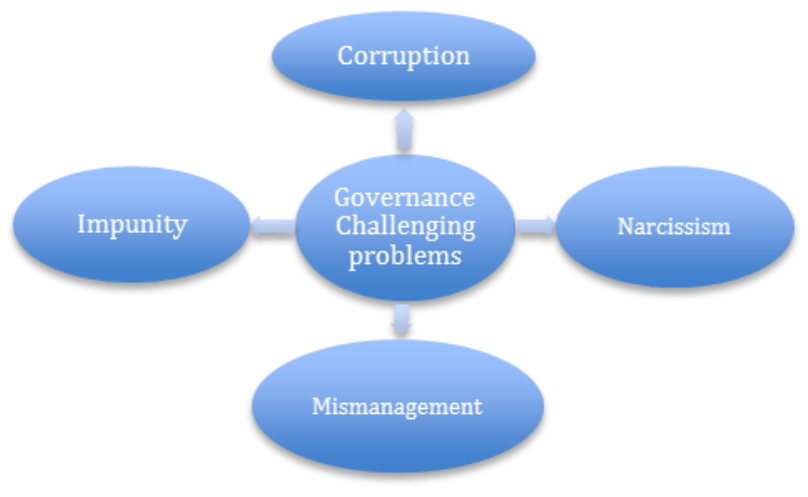

Figure 2.

Source: Author

\section{Good Governance in Guinea-Bissau}

The people of Guinea-Bissau as the people of Canada, Germany, Sweden, Ghana, Senegal or as the people of any other good country in the world dream to have better living standards and access to basic human needs such as: food, good education, good healthcare, improved drinking water, housing, sanitary facilities, and good roads. They want to live in a peaceful country. All needed things are only accessible through good and sound governance. Good governance before anything can be defined as "the transformation of good ideas into good practice in an effective manner for achieving outstanding outcome." But, the biggest problem Guinea-Bissau's governments have been facing is the mismanagement of the country's resources.

The word "good governance" is now new "idol" in the administrative system and in democratic governance theories. Multilateral agencies in developed countries over years 
succeeded as a result of the widely promoted concept "governance" to "good governance." The term "Good governance" requires government more innovative elements in exercising management of public office with good manners to achieve expected goals for the development of the country. According to the definition of The Asian Development Bank, good governance is "the manner in which power is exercised in the management of a country's economic and social resources for development" (AsDB, 1995). The United Nations Development Programme defined it as "the exercise of economic, political and administrative authority to manage a country's affairs at all levels" (UNPD, 1997). For World Bank good governance is "the manner in which power is exercised in the management of a country's economic and social resources for development" (World Bank, 1992). Lately, The African Development Bank states governance as a process referring to the way in which power is exercised in the management affairs of a nation (AfDB, 1999).

The successive failures of different Governments and Presidents in Guinea-Bissau over decades is resulting in imperfection of embarrassing national matters like political instability, cronyism, nepotism, corruption, politicization of public administration, mismanagement, social division based on gender, religion, political loyalty, extreme poverty, constant conflict of interest, ad infinitum. The people are debilitated and distressed by ineffective policies of different governments and clownery and greediness of politicians, indeed, there is no concerned expression for the people livelihood. By this reason, leaders are targeting at only very few people (elites) of the country. The country is being poorly governed and the politicians are failing. According to Diogo Lacerda, the president of the largest private bank in the country (BAO), Guinea-Bissau's people deserve another political elite (Conosaba, October 20, 2016). The Guinean movie director, Flora Gomes, described the situation even worst and said: "Guinea-Bissau is an airplane with a blind and deaf pilot. (Conosaba, October 12, 2015).

\section{The State of Good Governance in Guinea-Bissau}

Guinea-Bissau is one of the world's poorest and most fragile countries, the country has suffered from frequent political upset and repeated economic shocks, leading it into a fragility and poverty trap that has made it difficult to achieve and sustain development outcomes (World Bank, 2015). The people of Guinea-Bissau have lost hope and faith in their leaders because of constant failures of different governments at many levels over decades. It is noticeable to see that more than half of Guinea-Bissau's people are still living in extreme poverty. According to the IMF and INE-Guinea-Bissau reports, $69.3 \%$ of the population are living under $\$ 2$ a day, and 33.0\% living under \$1 a day (IMF, 2015; INE-ILAP, 2010). In 2014 Guinea-Bissau was ranked 177 out of 188 countries in Human Development Index (UN-HDI, 2015; HDR, 2015), and 40 out of 100 countries (2012 Ibrahim Index of African Governance), Guinea-Bissau's HDI value for 2014 is 0.420 percent which put the country in the low human development category. The unemployment rate is probably around $30 \%$ (DENARP II, 2011).

\section{Guinea-Bissau's Poverty Reduction Strategy Papers (DENARP I and DENARP II)}

Seeking for good governance and Poverty Reduction Guinea-Bissau's government launched 
in 2004 its first Poverty Reduction Strategy Paper "DENARP I" five years programme 2005/2010 and improved with second Poverty Reduction Strategy Paper "DENARP II" launched in 2011 for the 2011/2015 five years programme. The Papers set out "poverty reduction" as key guideline on which the programmes are based to achieve the objectives set by 2015 , but with the latest developments which culminated in overthrow of democratically elected government in April 12, 2012, does not give Guinea-Bissau the slightest chance to move forward towards consolidating of this objective, even if this crisis did not take place, it would be impossible to reach the goal, and in this situation Guinea-Bissau is automatically excluded from the scenario of reaching Millennium Deployment Goals. In a critical view, the Poverty Reduction Strategy Papers I and II have very limited vision in considering the country's development situation. The papers would have to focus on and consider in a much more ambitious development vision which expresses the aspiration of the Guinean people, public entities and private institutions for the country's development and economic growth, but not just thinking about a narrow project - "poverty reduction". Strangely, the needed elements for supporting good governance like: Accountability, Transparency, Combating Corruption, Participation, Legal and Judiciary reforms (AfDB, 1999) are ignored. The papers are unambitious and less inspired in terms of development and the people's aspirations. The papers should focus on a long-term vision of development that entitlements Guinea-Bissau's economic growth, encouraging foreign investment, promote agricultural and agro-industry projects, invest in building infrastructures, housing, industrialization, construction and production to stabilize internal market to reduce dependence from foreign import, human capital development programs, and modernize outdated education and healthcare system.

\section{Strategic and Operational Plan for 2015-2020 "Terra Ranka"}

"Terra Ranka" which means "new beginning" is a "Strategic and Operational Plan of Guinea-Bissau's Government for 2015-2025," officially launched in round table with donors' conference at the Brussels, Belgium in March 25, 2015. The round table organized and promoted by the Government of Guinea-Bissau with its main partners - European Union (EU) and the United Nations Development Programme (UNDP). Achieving more than $€ 427$ million of financial support to implement its development strategy for the next ten years was the goal of the Government of Guinea-Bissau for this round table of donors.

Building on the priorities identified by the authorities in their ambitious strategic and operational plan for the next five years, the partners decided to devote more than $€ 1$ billion to Guinea-Bissau to achieve its objectives and to achieve tangible improvements in the living conditions of the People of Guinea-Bissau. Donor's conference in Brussels was great opportunity to the government of Guinea-Bissau and brought back hope of the people of Guinea-Bissau because of very fruitfully result. This round table makes Guineans feel a lot more comforted because it was very important to bring a strategic vision to Brussels and to share it with our partners and to hear from our partners the availability of the necessary mechanisms to build the necessary partnership for the future" (Lusa; RFI; Radio Difusâo Nacional, March 25, 2015).

The Guinea-Bissau 2025 Plan "Terra Ranka” represents an ambitious plan to transform 
Guinea-Bissau in a decade. It will be implemented from 2015-2020 in six axis, twenty-three (23) fields of action, fifty-three (53) programmes and 115 projects, for a cost of 1305 billion CFA francs (Terra Ranka, 2015). Terra Ranka is a complete idea with head, trunk and limbs. Government of Guinea-Bissau selected five policy areas for implementing governance at the service of the citizen and sustainable development. The Government shall pursue five main goals within this framework: (i) reform and modernise public administration (ii) provide good management of security and defence, (iii) reform the legal system and build a State of law, (iv) improve macroeconomic management and reform public finance management, and (v) promote local development, decentralisation and citizen participation (Terra Ranka, 2015). The strategic and operational plan 2015-2025 Terra Ranka is very good plan which is clearly described fundamental and real problems of Guinea-Bissau for needed development. With good implementation the operational plan can help Guinea-Bissau to find solutions sought to achieve good governance. The question is, how to implement this Strategic and Operational plan with constant political instability?

\section{Conclusion}

It will be very difficult to consolidate the process of democratization and achieving good governance or building consensus among political parties on the main political and administrative reforms that the country needs. While there is political myopia and "denial of the truth." One of Guinea-Bissau's problems is the excessive embodiment of political life to control power and get money. Politicians each one is rowing boat to own direction, their minds are full malfeasance and narcissisms oriented by private benefit over national interest. If incompetence takes place of competence, indiscipline succeeds discipline, misconduct put in place of conduct, then misleaders take control of everything to misguide the society. Guinea-Bissau is facing serious and too many problems in its governance system because of a weakened administration system in which the institutions do not work. Each head of the department leads the state institutions as they wish for the private benefit, without respecting the constitution and others rules. Rule of law is completely out of the system. State institutions are administratively managed as personal email, and economically as a personal wallet. Each leader is god of the institutions he/she directs. There is no respect for the law.

\section{Recommendations}

Guinea-Bissau needs very strong leadership with values that symbolize national unity and create sound and stable society to fight and defeat political and social ills. Give voice to ordinary people and to place women, the young, the uneducated, the excluded, and the poor people we have in the communities.

Guinea Bissau must reform and modernize public administration based on decentralization and de-concentration policy sharing power from central to local government, local government to the community. Build state of law and reorganize legal system. Incentive some fundamental principles as: citizenship and respect for the human right. These principles are capable of dragging a society such as Guinean towards a higher level of human development, especially for gender equality and durable subsistence. For this reason, the concept of governance for human development is always necessary. 


\section{Macrothink}

Journal of Public Administration and Governance

ISSN 2161-7104

2017, Vol. 7, No. 2

The international community and many others development agencies including bilateral partners have been very supportive of Guinea-Bissau for decades by giving expeditious aid and some technical supports in resolving punctual problems especially in critical moment of the country. The question is that can these aids solve the problems of the country and bring solutions? The answer would be no. Aids don't solve the problems of long term. Aid is not solution for Guinea-Bissau. The aid should be replaced by the investment. The country needs investment in education, healthcare, big projects like building network infrastructure, develop agriculture and produce locally to boost economy, reduce import and increase export to stabilize domestic market. Explore new technology for industrialization to guarantee food safety in first place

\section{References}

UN Human Development Index. (2015).

Huntington: The Third Wave: Democratization in the Late Twentieth Century. (1991).

UN Human Development Report 2015 on Guinea-Bissau.

Ibrahim Index of African Governance. (2012).

Strategic and Operational Plan R 2015-2020 “Terra Ranka"

UNDP. (2006). Definition of basic concepts and terminologies in governance and public administration.

Said Adejumobi. Africa and the Challenges of Democracy and Good Governance in the $21^{\text {st }}$ Century.

Ture, Iaia Maria. (2016). Política, Caráter e Lideraça: Tudo em torno da Verdade.

Dirk Kohnert. Democratization via Elections in an African "Narco-state"? The Case of Guinea-Bissau.

Robin Theobald. (1990). Corruption, Development and Underdevelopment.

Lars Rudebeck. On Democratization Sustainability-Transition in Guinea-Bissau, Sida Studies n.4

Roy van der Drift1, Democracy: Legitimate warfare in Guinea-Bissau.

Tcherno Djalo, Licoes e Legimitidade dos Conflitos na Guine-Bissau.

Iaia Ture. (2010). A Honestidade Faz Parte da Política Moderna www.didinho.org

As crises Político-Militares na Guiné-Bissau: Causas, problemas e Soluções.

Christoph Kohl, Construindo a nação na Africa pós-colonial:o exemplo de Guiné-Bissau.

IMF, Guinea-Bissau: Poverty Reduction Strategy Paper DENARP I.

Voz di Paz, Roots of Conflicts in Guinea-Bissau: The voice of the people. 


\section{Macrothink}

Journal of Public Administration and Governance

Iaia Ture. (2011). Optismo: http://www.didinho.org/Arquivo/OPTIMISMO2011.htm

Inge Amundsen. (1999). Political Corruption: An Introduction to the Issues, WP 1999: 7.

Transparency International. (2016).

Iaia, Ture. A Liberdade Conquista Contra Dominio Portuges é uma Honra.

Iaia Ture. Nada Vale uma Palavra sem Sentimento Verdadeiro. www.didinho.org

Iaia Ture. (2014). ESPERANÇA DE VER UMA NOVA GUINÉ-BISSAU.

http://novasdaguinebissau.blogspot.com/2014/10/presidente-da-republica-faz-duras.html

http://www.gbissau.com/?p=9374

http://expresso.sapo.pt/africa/nenhum-presidente-eleito-na-guine-bissau-cumpre-mandato-ate -ao-fim=f698776

http://www.dw.com/pt-002/corrupção-na-guiné-bissau/t-17417970

Ministério da Função Pública, Trabalho e Modernização do Estado: Recenseamento Biometrico, 2010.

Ministério da Administraçâo Territorial e Ordenamento do Territorio: Programa Nacional de Descentralizaçâo, 2015.

Guinea-Bissau: II Poverty Reduction Strategy Paper - DENARP II.

\section{Copyright Disclaimer}

Copyright for this article is retained by the author(s), with first publication rights granted to the journal.

This is an open-access article distributed under the terms and conditions of the Creative Commons Attribution license (http://creativecommons.org/licenses/by/4.0/). 